\title{
COVERAGE OF CLIMATE CHANGE TRENDS IN ZHYTOMYR OVER A 19-YEAR PERIOD
}

\author{
Herasymchuk L. O., Valerko R. A.
}

\section{INTRODUCTION}

Climate change has been one of the main problems at the international level since 1980s, and it is the major challenge to government authorities and society at large. The Sustainable Development Goals of Ukraine until $2030^{1}$, the Strategy of the State Environmental Policy until $2030^{2}$ and the Concept of Its Implementation ${ }^{3}$ recognize climate change as one of the main problems in the world development; it is a challenge for the fulfillment of tasks of the global economy and international security, since it directly affects energy security, food and water supply, sustainability of ecosystems, occurrence of emergency situations, risks to people's lives and health.

According to the information available in the reports ${ }^{4,5,6,7,8,9,10}$ of Intergovernmental Panel on Climate Change that was established in 1988 and deals with assessment of climate change, its consequences, future risks and possible response options ${ }^{11}$, the average air temperature is increasing in all

\footnotetext{
${ }^{1}$ Про Цілі сталого розвитку України на період до 2030 року: Указ Президента України від 30 вересня 2019 р. № 722/2019. URL: https://zakon.rada.gov.ua/rada/show/722/2019.

2 Про Основні засади (стратегію) державної екологічної політики України на період до 2030 року: Закон України від 28 лютого 2019 р. № 2697-VIII. URL: https://zakon.rada.gov.ua/laws/show/2697-19.

3 Концепція реалізації державної політики у сфері зміни клімату на період до 2030 року: Розпорядження Кабінету Міністрів України від 07 грудня 2016 р. № 932-p. URL: https://zakon.rada.gov.ua/laws/show/932-2016.

${ }^{4}$ Annual Report 2017: UN Climate Change. URL: https://unfccc.int/resource/annualreport.

${ }^{5}$ Climate Change 1995: Second Assessment: Report of the intergovernmental panel on climate change. URL: https://www.ipcc.ch/site/assets/uploads/2018/06/2nd-assessment-en.pdf.

${ }^{6}$ Climate Change 2001: The Scientific Basis. Contribution of Working Group I to the Third Assessment Report of the Intergovernmental Panel on Climate Change [Houghton, J.T., Y. Ding, D.J. Griggs, M. Noguer, P.J. van der Linden, X. Dai, K. Maskell, and C.A. Johnson (eds.)]. Cambridge University Press, Cambridge, United Kingdom and New York, NY, USA, 2001. 881 pp. URL: https://www.ipcc.ch/site/assets/uploads/ 2018/03/WGI_TAR_full_report.pdf.

${ }^{7}$ Climate Change 2007: Synthesis Report. Contribution of Working Groups I, II and III to the Fourth Assessment Report of the Intergovernmental Panel on Climate Change [Core Writing Team, Pachauri, R.K. and Reisinger, A. (eds.)]. IPCC, Geneva, Switzerland, 2007. 104 pp. URL: https://www.ipcc.ch/site/assets/ uploads/2018/02/ar4_syr_full_report.pdf.

${ }^{8}$ Climate Change 2014: Synthesis Report. Contribution of Working Groups I, II and III to the Fifth Assessment Report of the Intergovernmental Panel on Climate Change [Core Writing Team, R.K. Pachauri and L.A. Meyer (eds.)]. IPCC, Geneva, Switzerland, 2014. 151 pp. URL: https://www.ipcc.ch/site/assets/ uploads/2018/05/SYR_AR5_FINAL_full_wcover.pdf.

${ }^{9}$ Climate Change and Land 2019: An IPCC Special Report on climate change, desertification, land degradation, sustainable land management, food security, and greenhouse gas fluxes in terrestrial ecosystems. URL: https://www.ipcc.ch/site/assets/uploads/2019/08/Edited-SPM_Approved_Microsite_FINAL.pdf.

${ }^{10}$ Climate Change: The IPCC Scientific Assessment - 1st Report: World meteorological organization. URL: https://www.ipcc.ch/site/assets/uploads/2018/03/ipcc_far_wg_I_full_report.pdf.

${ }^{11}$ The Intergovernmental Panel on Climate Change, IPCC. URL: https://www.ipcc.ch.
} 
regions of the world. The reason for this is anthropogenic effect on the climatic system.

According to World Meteorological Organization ${ }^{12}$, 2015-2018 were four warmest years since observations began. This is an indication of a longlasting climate change, which is associated with the peak concentration of greenhouse gases in the atmosphere.

The analysis of WMO data showed that the global average surface temperature in 2018 was by about $1{ }^{\circ} \mathrm{C}$ higher than the pre-industrial basic level (1850-1900). This year was ranked 4th among the warmest years since observations began ${ }^{13}$.

In Ukraine, little attention is given to the issues of climate change at the state level despite the fact that a number of international documents in this field have been signed and ratified and climate change has been recognized as one of the main problems of the world development. At the same time, issues of climate change and its consequences for all life spheres are constantly emphasized in the EU countries. At present, all state efforts in Ukraine are focused on defensive capacity, power industry and economic development ${ }^{14}$. However, consequences of climate change are observed at all levels (local, regional, national and global) and should be definitely taken into account when the state policy is shaped and implemented.

Climate change (over the past 100 years, average annual air temperature in Ukraine has increased by $0.6 \pm 0.2{ }^{\circ} \mathrm{C}$, while the amount of precipitation by $5-7 \%{ }^{15}$ ) affects all economic sectors and will lead to the increase of temperature regime ${ }^{16,17}$, growing amount of abnormal temperatures and atmospheric precipitation $^{18}$, negative consequences for agriculture ${ }^{19,20}$, up to climatic upheaval ${ }^{21}$.

\footnotetext{
${ }^{12}$ World Meteorological Organization. URL: https://public.wmo.int/en.

${ }^{13}$ Global Warming of $1.5^{\circ} \mathrm{C}$ : IPCC Special Report on the impacts of global warming of $1.5^{\circ} \mathrm{C}$ above pre-industrial levels and related global greenhouse gas emission pathways, in the context of strengthening the global response to the threat of climate change, sustainable development, and efforts to eradicate poverty. IPCC, Switzerland, 2018. 32 pp. URL: https://report.ipcc.ch/sr15/pdf/sr15_spm_final.pdf.

${ }^{14}$ Кліматична дипломатія в ЄС: висновки та рекомендації для України: аналітичний документ. Львів: Експертно-дорадчий центр «Правова аналітика», 2017. 39 c. URL: https://www.rac.org.ua/ uploads/content/371/files/climate-diplomacy.pdf.

${ }^{15}$ Boychenko S., Voloshchuk V., Movchan Ya., Serdjuchenko N., Tkachenko V., Tyshchenko O., Savchenko S. Features of climate change on Ukraine: scenarios, consequences for nature and agroecosystems. Proceedings of National Aviation University. 2016. Vol. 69, № 4. P. 96-113. DOI: https://doi.org/10.18372/2306-1472.69.11061.

${ }^{16}$ Польовий А.М., Божко Л.Ю. Характеристика радіаційно-теплових ресурсів в Україні на період до 2050 р. в умовах зміни клімату. Украӥнський гідрометеорологічний журнал. 2016. № 17. С. 70-78. URL: http://nbuv.gov.ua/UJRN/Uggj_2016_17_10.

${ }_{17}$ Хохлов В.М., Боровська Г.О., Уманська О.В., Тенетко М.С. Зміна погодних умов на території України в умовах зміни клімату. Украӥнський гідрометеорологічний журнал. 2016. № 17. С. 31-37. URL: http://nbuv.gov.ua/UJRN/Uggi_2016_17_6.

${ }_{18}$ Осадчий В.І., Бабіченко В.М. Температура повітря на території України в сучасних умовах клімату. Український географічний журнал. 2013. № 4. С. 32-39. DOI: https://doi.org/10.15407/ ugz2013.04.032.
} 
The issues of climate change have been reflected in the papers of Ukrainian $^{22,23,24,25,26}$ and foreign scientists ${ }^{27,28,29,30}$. However, despite the significant amount of available data there is a lack of studies related to the climate change in Ukrainian cities, including the Zhytomyr region, which was the reason for this study. In addition, consequences of climate change are more noticeable at the local level.

Thus, the purpose of the study was to assess the manifestations of climate change in Zhytomyr during 2000-2018.

The informational basis for the study was the data on average annual and monthly air temperature and amount of precipitation in Zhytomyr, which was received from the Zhytomyr Regional Centre for Hydrometeorology.

The coefficient of deviation essentiality (CDE) of air temperature and precipitation amount from the average values was calculated using the methodology presented in the work of Pedia D.A. ${ }^{31}$. It was calculated in the context of years and months under investigation. The statistical processing of the obtained data was carried out using Microsoft Excel and Statistica 6.0.

\footnotetext{
${ }^{19}$ Прокопенко К.О., Удова Л.О. Сільське господарство України: виклики і шляхи розвитку в умовах зміни клімату. Економіка і прогнозування. 2017. № 1. C. 92-107. DOI: https://doi.org/10.15407/ eip2017.01.092.

${ }^{20}$ Хромяк В.М., Наливайко В.В. Ризики ведення рослинництва в умовах Північно-східного Степу в зв'язку зі зміною клімату. Вісник аграрної науки. Вересень 2016. C. 17-24. DOI: https://doi.org/ 10.31073/agrovisnyk201609-03.

${ }^{21}$ Гребенюк Н.П. Характеристика повторюваності сильних злив на території України в умовах сучасних змін клімату. Гідрологія, гідрохімія $i$ гідроекологія. 2014. Т. 1. С. 96-101. URL: http://nbuv.gov.ua/UJRN/glghge_2014_1_13.

${ }^{22}$ Балабух В.О. Регіональні прояви глобальної зміни клімату в Тернопільській області та можливі їх зміни до середини XXI ст. Наукові записки Тернопільського національного педагогічного університету імені Володимира Гнатюка. Сер. Географія. 2014. № 1. С. 43-54. URL: http://nbuv.gov.ua/UJRN/NZTNPUg_2014_1_9.

${ }^{23}$ Валерко Р.А. Екологічна оцінка змін клімату на території м. Коростень Житомирської області. Вісник ЖНАЕУ. 2015. № 2 (50), т. 1. С. 46-54.

24 Герасимчук Л.О., Валерко Р.А., Мартенюк Г.М. Тенденції зміни клімату на території м. Новоград-Волинський Житомирської області. Наукові горизонти. 2018. № 2 (65). С. 42-50. URL: http://ir.znau.edu.ua/handle/123456789/9497.

${ }^{25}$ Кириленко В.В., Волощук С.І., Дубовик Н.С., Близнюк Б.В. Ретроспективний аналіз погодних умов у зоні діяльності Миронівського інституту пшениці. Миронівський вісник. 2016. Вип. 2. С. 87-97. DOI: https://doi.org/10.21498/2518-7910.0.2016.119548.

${ }^{26}$ Гетьманчук А.І., Кичилюк О.В., Войтюк В.П., Бородавка В.О. Регіональні зміни клімату як причина гострих всихань сосняків Волинського Полісся. Науковий вісник НЛТУ Украӥни. 2017. Vol. 27, № 1. P. 120-124. DOI: https://doi.org/10.15421/40270127.

${ }^{27}$ Староватов А.А. Некоторые аспекты изменения климата земли. Web of Scholar. 2018. № 6(24), T.2. C. 52-54. DOI: 10.31435/rsglobal_wos/12062018/5754.

28 Ho E.H., Budescu D.V. Climate uncertainty communication. Nat. Clim. Chang. 2019. № 9. P. 802-803. DOI:10.1038/s41558-019-0606-6.

${ }^{29}$ Jerry M. Melillo et al. (eds.). Highlights of Climate Change Impacts in the United States: The Third National Climate Assessment, USGCRP (Washington, DC: U.S. Government Printing Office, 2014). URL: http://www.globalchange.gov/sites/globalchange/files/NCA3_Highlights_LowRes-smallFINAL_posting.pdf.

${ }^{30}$ Massimiliano Pasqui, Edmondo Di Giuseppe. Climate change, future warming, and adaptation in Europe. Animal Frontiers. 2019. Vol. 9, № 1. P. 6-11. https://doi.org/10.1093/af/vfy036.

${ }^{31}$ Педь Д.А. О показателе засухи и избыточного увлажнения. Труды Гидрометиентра СССР. 1975. Вып. 156. С. 19-38.
} 


\section{Trends in the change of air temperature in the city}

Changes in the values of average air temperature characterize the intensity of change in the temperature regime. It has been found that average temperature during all months over 2000-2018 differed from the norm by 0.8 (in October) $-2.6^{\circ} \mathrm{C}$ (in July). As for other months of the year, over 2008-2018 January became warmer on average by 2.5, March by 2.4, December and August by 2.3, April by 2.2, February by 2.0, November by 1.7 , May by 1.6 , June by 1.5 , September by $1.2^{\circ} \mathrm{C}$ (Fig. 1 ).
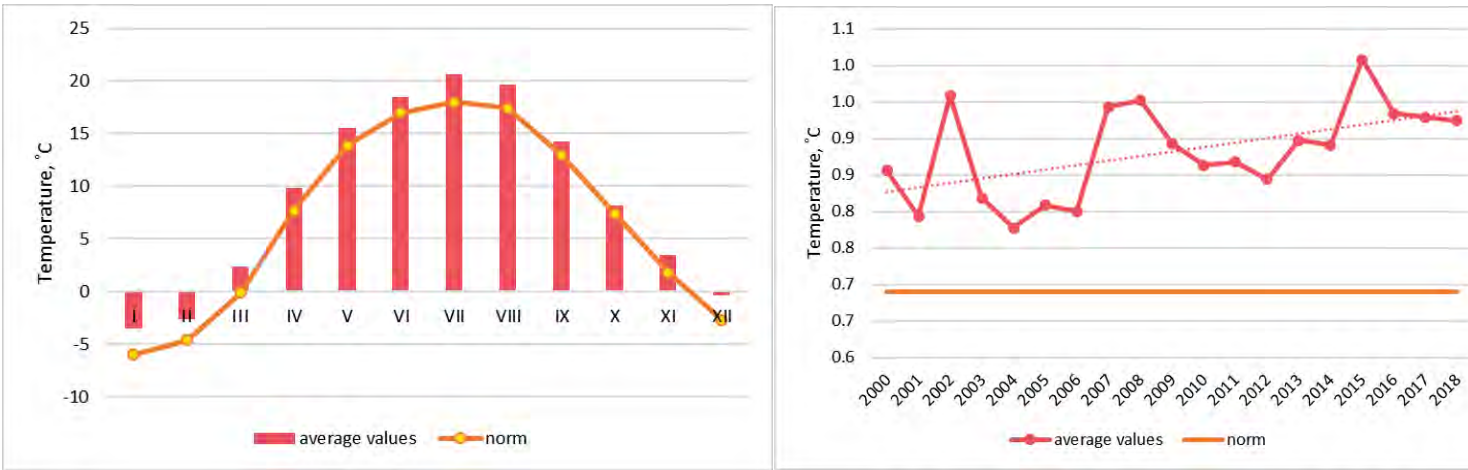

Fig. 1. Dynamics in the changes of average annual air temperature on the territory of Zhytomyr during 2000-2018

Table 1

Statistical parameters of average annual temperature in Zhytomyr over 2000-2018

\begin{tabular}{|c|c|c|c|c|c|}
\hline Years & $\mathrm{x}_{\mathrm{cp}}$ & $\min$ & $\max$ & $\mathrm{S}^{*}$ & $\mathrm{~V}, \%$ \\
\hline $2000-2010$ & 8.6 & $7.78(2004)$ & $9.58(2002)$ & 0.20 & 2.36 \\
\hline $2011-2018$ & 9.12 & $8.44(2012)$ & $10.08(2015)$ & 0.18 & 1.93 \\
\hline
\end{tabular}

$* \mathrm{~S}$ - standard error; $\mathrm{V}$ - coefficient of variation

In the context of years under investigation, the deviation from the climatic norm was in the range from 0.9 (2004) to 3.2 (2015) ${ }^{\circ} \mathrm{C}$ (Fig. 1). Thus, 2015 was the warmest year over the period of observations, while the highest temperature increase occurred in the first half of the year.

On average, over 2000-2018 the air temperature increased by $1.9^{\circ} \mathrm{C}$ compared to climatic norm (during 2000-2010 the temperature rise was $1.7^{\circ} \mathrm{C}$, while during $2011-2018$ it was $2.2^{\circ} \mathrm{C}$ ). During the winter season in 2000 2018 , the value of average monthly temperature rose by $2.3^{\circ} \mathrm{C}$, during spring and summer season by $2.1^{\circ} \mathrm{C}$, during autumn season by $1.2^{\circ} \mathrm{C}$. In the context of the months, the temperature rise is as follows: July (by $\left.2.6^{\circ} \mathrm{C}\right)>$ September (by $2.5^{\circ} \mathrm{C}$ ) $>$ March (by $2.4^{\circ} \mathrm{C}$ ) $>$ August and December (by $2.3^{\circ} \mathrm{C}$ ) $>$ April (by $2.2^{\circ} \mathrm{C}$ ) $>$ February $>\left(\right.$ by $2.0^{\circ} \mathrm{C}$ ) $>$ November (by $1.7^{\circ} \mathrm{C}$ ) $>$ May $\left(\right.$ by $1.6^{\circ} \mathrm{C}$ ) $>$ June (by $1.5^{\circ} \mathrm{C}$ ) $>$ September (by $1.2^{\circ} \mathrm{C}$ ) $>$ October (by $0.8^{\circ} \mathrm{C}$ ) (Fig. 2). 


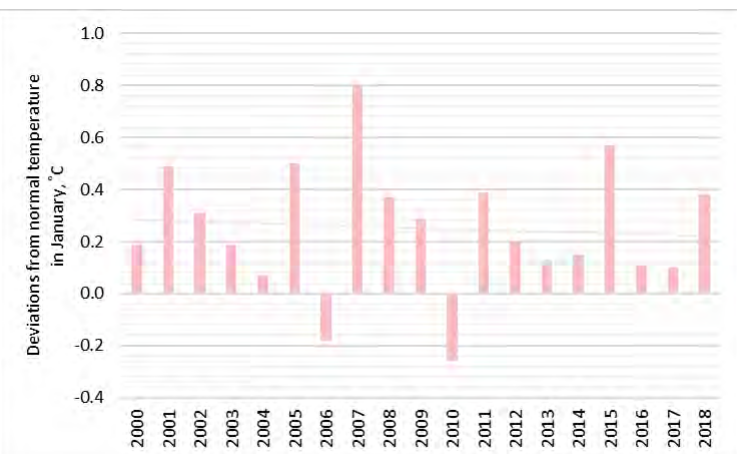

a)

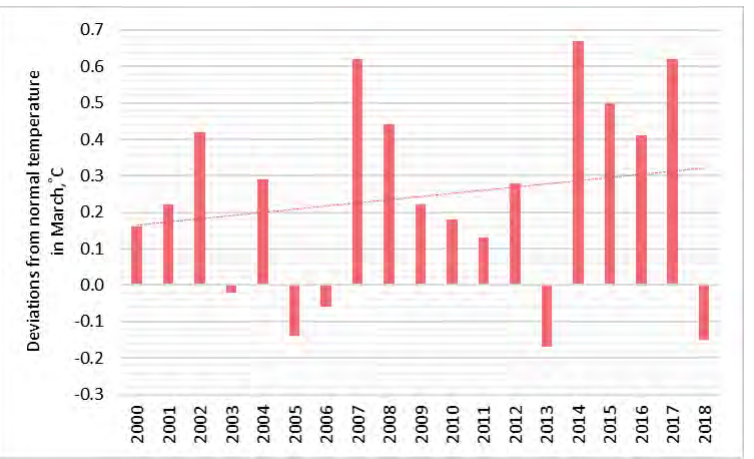

c)

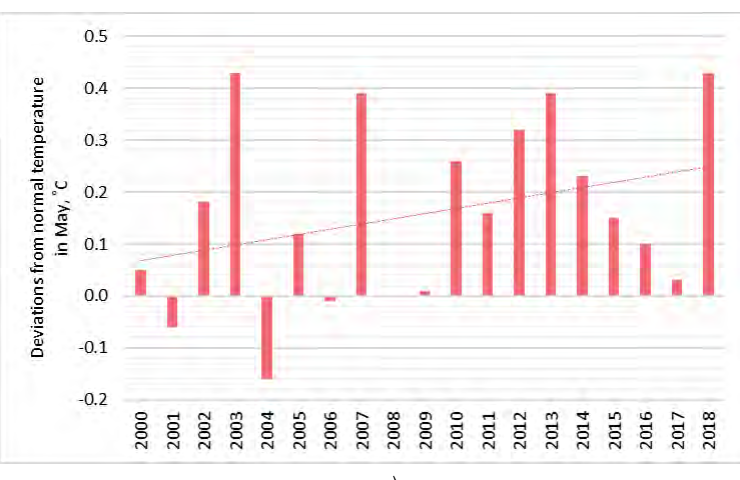

e)

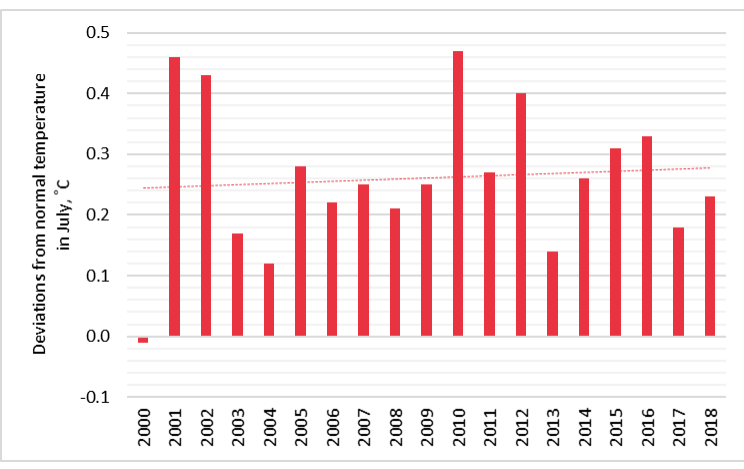

g)

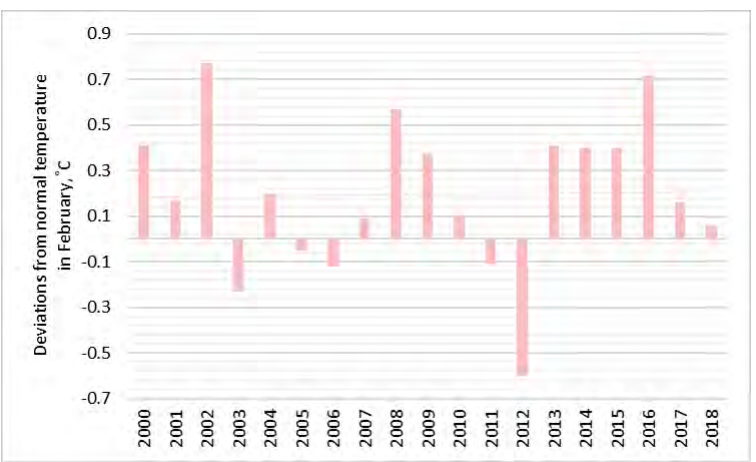

b)
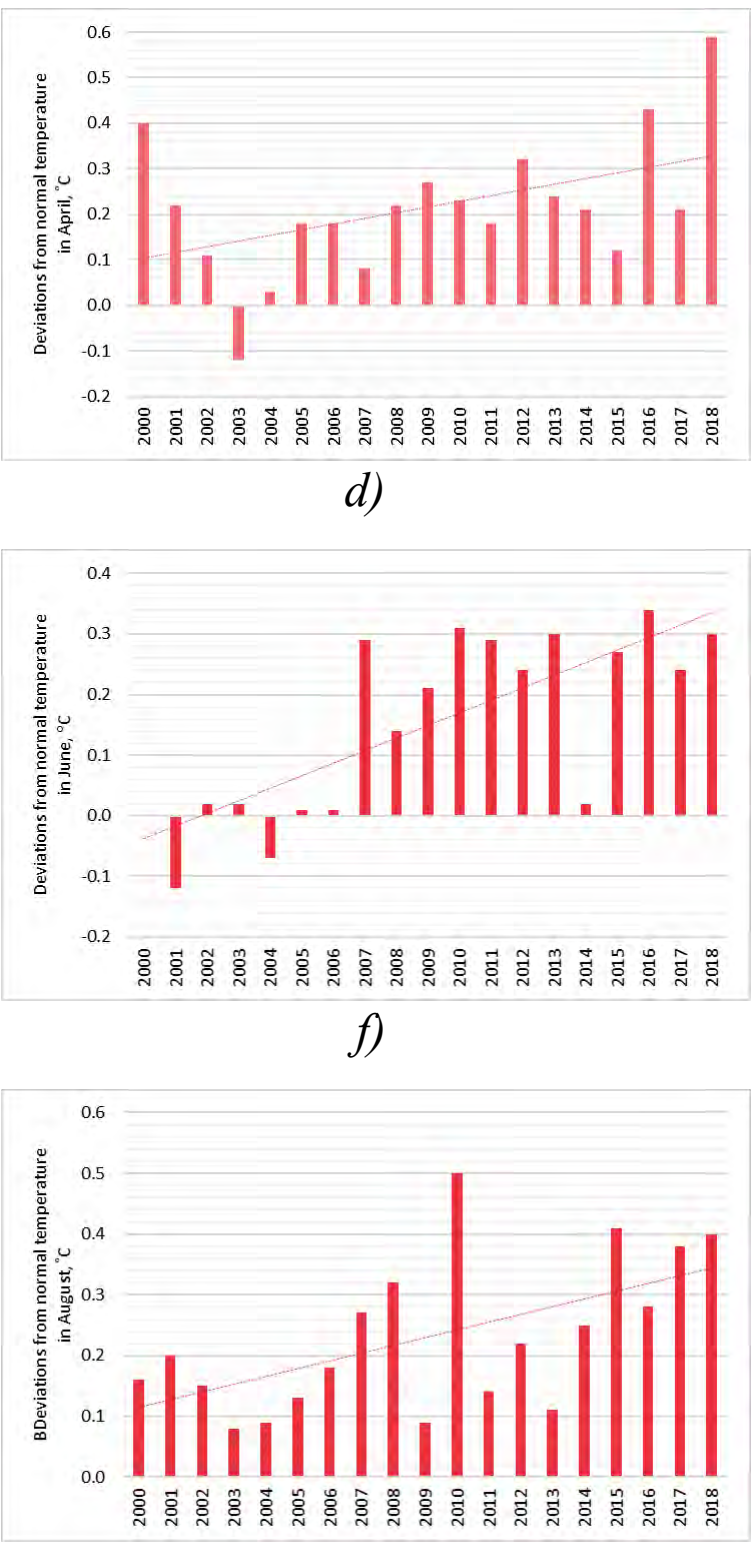

h)

Fig. 2. Deviation from normal average monthly temperature during 2000-2018 


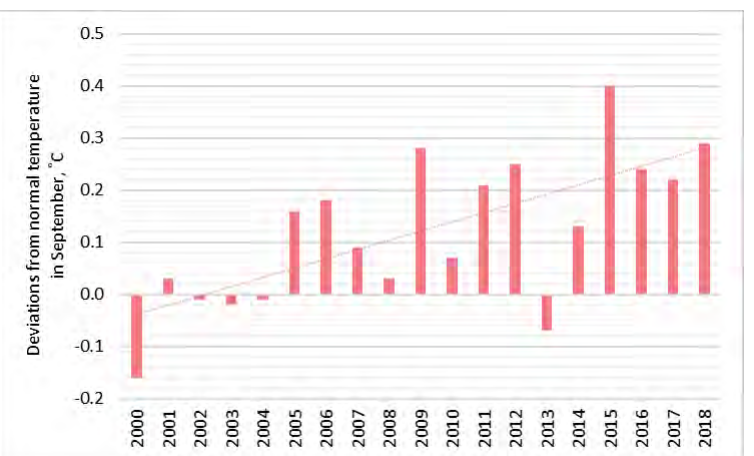

i)

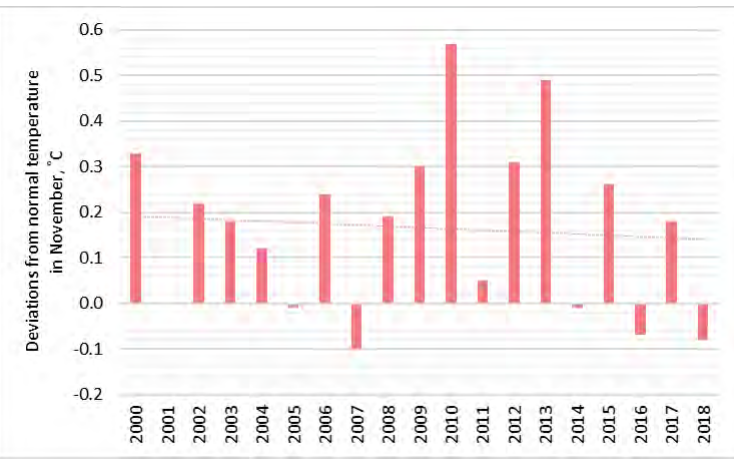

k)

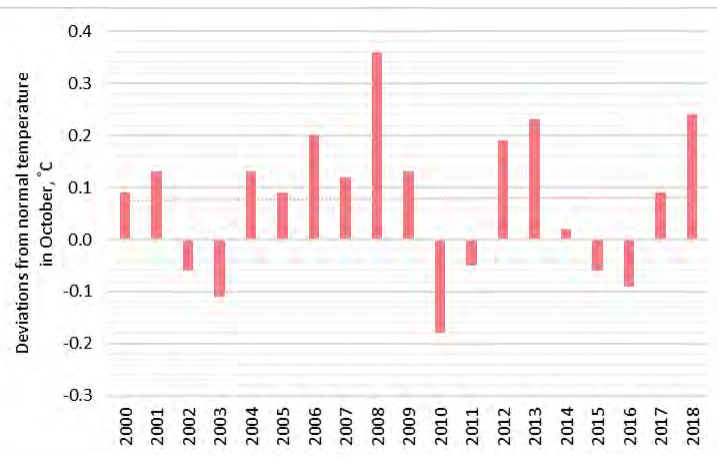

j)

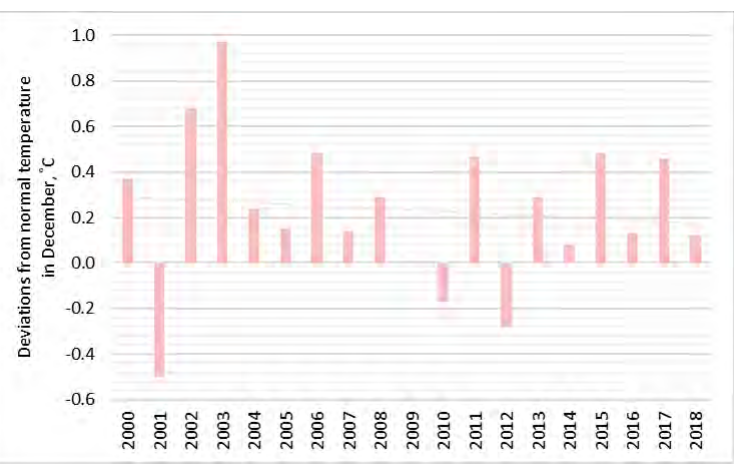

l)

Fig. 2. (Continued)

Over 2000-2018, average monthly temperature in January deviated from the norm by $0.7(2004)-8.0(2007){ }^{\circ} \mathrm{C}$ towards rise (climatic norm for January in Zhytomyr is $6.0^{\circ} \mathrm{C}$ ) (Fig. 2a), in February by 0.6 (2018) $7.7(2002){ }^{\circ} \mathrm{C}$ (Fig. 2b), in March by 1.3 (2011) - 6.7 (2014) ${ }^{\circ} \mathrm{C}$ (Fig. 2c), in April by 0.3 (2004) -5.9 (2018) ${ }^{\circ} \mathrm{C}$ (Fig. 2d), in May by 0.1 (2009) 4.3 (2003 and 2018) ${ }^{\circ} \mathrm{C}$ (Fig. 2e), in June by 0.1 (2005 and 2006) $3.4(2016){ }^{\circ} \mathrm{C}$ (Fig. 2f), in July by 1.2 (2004) -4.7 (2010) ${ }^{\circ} \mathrm{C}$ (Fig. $2 g$ ), in August by $0.8(2003)-5.0(2010){ }^{\circ} \mathrm{C}$ (Fig. 2h), in September by 0.3 (2001 and 2008) - $4.0(2015){ }^{\circ} \mathrm{C}$ (Fig. 2i), in October by $0.2(2014)-$ $3.6(2008){ }^{\circ} \mathrm{C}$ (Fig. $2 j$ ), in November by 0.5 (2011) - 5.7 (2010) ${ }^{\circ} \mathrm{C}$ (Fig. $2 k$ ), in December by $0.1(2009)-9.7(2003){ }^{\circ} \mathrm{C}$ (Fig. $\left.2 l\right)$.

It should be noted that only $1.3 \%$ of values of average monthly temperature met the climatic norms (in May 2008, in June 2000 and in November 2001). Over 2000-2018 only $16.2 \%$ of values of average monthly temperature were lower than the norm of average monthly temperature: in January 2006 and 2010 (Fig. 2a), in February 2003, 2005, 2006, 2011 and 2012 (Fig. 2b), in March 2003, 2005, 2006, 2013 and 2018 (Fig. 2c), in April 2003 (Fig. 2d), in May 2001, 2004 and 2006 (Fig. 2e), in June 2001 and 2004 (Fig. 2f), in July 2000 (Fig. 2g), in September 2000, 2002, 2003, 2004 and 2013 (Fig. 2i), in October 2002, 2003, 2010, 2011, 2015 and 2016 (Fig. 2j), in November 2005, 
2007, 2014, 2016 and 2018 (Fig. 2k), in December 2001, 2010 and 2012 (Fig. 2l).

Generally it can be concluded that Zhytomyr is characterized by the trend of rising average annual and monthly temperature, which indicates climate change towards warming. The consequences of the rise in air temperature compared to the climatic norm are extreme natural phenomena, changes of the yield capacity of agricultural crops, changes in biodiversity, and risks to human health, etc.

\section{Trends in the change of precipitation amount in the city}

Data on the dynamics of precipitation amount, just as air temperature, indicate climate change. Data on the precipitation amount and its distribution during the year is especially important for farming [1;2].

Over 2000-2018, the distribution of precipitation in Zhytomyr was uneven: maximum amounts of precipitation, which was $120-130 \%$ of the norm, occurred in 2001, 2007, 2012 and 2013, minimum amounts, 79-84\% of the norm, occurred in 2003, 2011 and 2015 (Fig. 3).

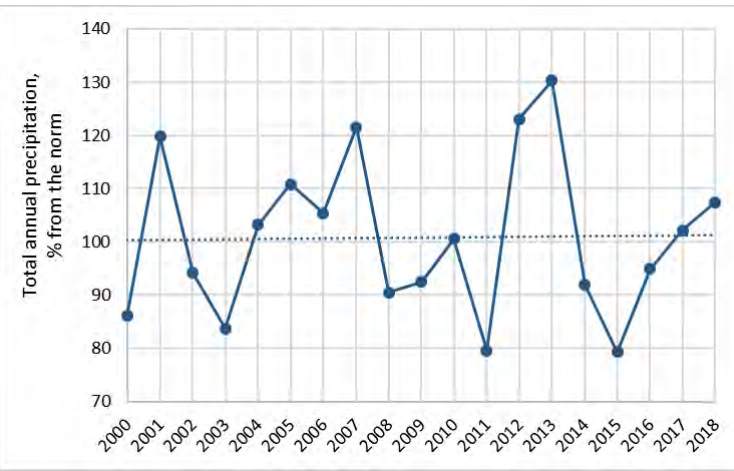

a)

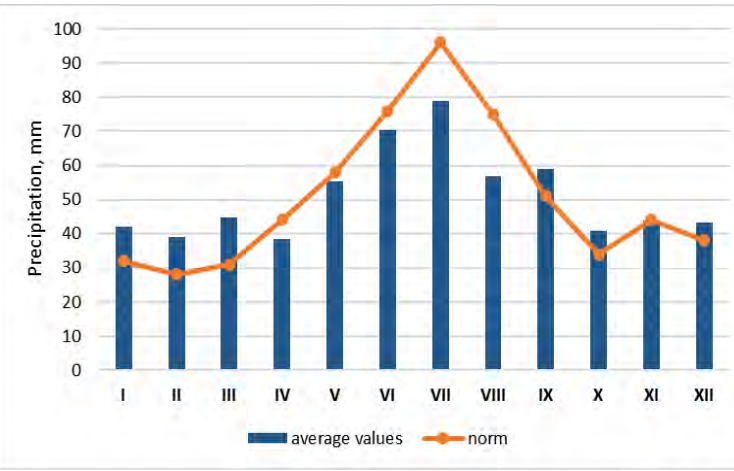

b)

Fig. 3. Dynamics of deviation of average annual precipitation amount from the norm in Zhytomyr during 2000-2018 in the context of years (\%) (a) and months (mm) (b)

During the period under investigation 2000-2018, average annual precipitation amount was $612.3 \mathrm{~mm}$ (climatic norm is $607 \mathrm{~mm}$ ).

Table 2

Statistical parameters of average annual precipitation amount in Zhytomyr over 2000-2018

\begin{tabular}{|c|c|c|c|c|c|}
\hline Years & $\mathrm{x}_{\mathrm{cp}}$ & $\min$ & $\max$ & $\mathrm{S}^{*}$ & $\mathrm{~V}, \%$ \\
\hline $2000-2010$ & 611.48 & $508.1(2003)$ & $737.7(2007)$ & 23.47 & 3.84 \\
\hline $2011-2018$ & 613.51 & $481.3(2015)$ & $791.0(2013)$ & 40.08 & 6.53 \\
\hline
\end{tabular}

$* \mathrm{~S}$ - standard error; $\mathrm{V}$ - coefficient of variation 
During the period under investigation, the amount of precipitation in Zhytomyr was uneven. Over 2000-2018, minimum amount of precipitation 4.1 and $6.4 \%$ of the norm - occurred during the autumn season: in October 2000 and in November 2011. 10\% of the precipitation of the norm was observed in August 2009 and 2015. September 2016 (13.7\%), June 2008 (14.1\%), July 2005 (15.4\%) and 2006 (19.5\%), September 2014 (15.9\%) and 2009 (16.7\%), October 2014 (17.6\%) were characterized by an insignificant amount of precipitation - from 10 to $20 \%$ of the norm. $20-30 \%$ of the norm of precipitation was observed in August 2016 (20\%), in May $2003(20.5 \%)$, in September 2005 (21\%), in December 2006 (21.1\%), in August (22,3\%) and in June (23,7\%) 2000, in June 2010 (25.8\%), in April 2016 (27,3\%), in May $2018(27.6 \%)$ and in October 2013 (28.5\%) (which amounted to 4.4\% of precipitation). During the period of observations, $30-40 \%$ of the precipitation norm occurred in 3.1\% of cases (March 2011 (30.6\%), June 2016 (31.6\%) and 2017 (39.5\%), February 2014 (33.2\%), May 2012 (37.6\%), July 2015 (37.8\%), April 2018 (38.6\%); 40-50\% of the precipitation norm occurred only in 8.3\% of cases (April 2009, 2010 (41.8\%) and 2004 (46.4\%), July 2002 (42.1\%), September 2011 (42.4\%), January 2006 (43.8\%), August 2001 (44.3\%), 2003 (48.1\%), 2008 (48.4\%) and 2010 (47.5\%), March 2010 (48.4\%), October 2008 (49.1\%), November 2009 (49.3\%), May 2002 (48.8\%) and $2017(49.9 \%)$ ); $50-60 \%$ of the precipitation norm occurred in $8.8 \%$ of cases (July 2008 (50.4\%), 2013 (52.7\%) and 2001 (58.5\%), April 2013 (50.7\%) and 2003 (53.2\%), November 2008 (50.9\%), 2018 (54.5\%) and 2006 (57.3\%), December 2013 (52.1\%) and 2004 (55.0\%), August 2018 (53.3\%) and 2014 (54.9\%), March 2007 (54.8\%), 2014 (55.2\%) and 2002 (55.8\%), June 2014 (55.4\%), May 2011 (55.5\%), February 2008 (57.5\%), October $2007(57.9 \%)$, January $2011(60.0 \%)) ; 60-70 \%$ of the precipitation norm occurred in $6.6 \%$ of cases (January $2002(61.3 \%)$, September $2012(62.0 \%)$ and 2015 (64.3\%), August 2017 (61.3\%) and 2011 (68.8\%), May 2013 (63.8\%) and 2007 (64.0\%), October 2001 (64.1\%), December $2011(64.2 \%)$ and 2007 (65.3\%), April 2007, 2011 (66.6\%) and 2015 (69.3\%), July 2012 (68.1\%), November $2003(68.2 \%)) ; 70-80 \%$ of the precipitation norm occurred in 7.02\% of cases (November 2002 (71.6\%), 2005 (73.2\%) and 2014 (80.0\%), June 2007 (71.7\%) and 2005 (72.2\%), April 2017 (72.7\%), July $2017(74.0 \%)$ and $2016(77.1 \%)$, May $2001(74.5 \%)$ and $2000(75.7 \%)$, December 2003 (75.8\%), 2008 (76.3\%), 2001 (78.4\%) and 2000 (78.9\%), January 2009 (77.5\%), February $2015(80.0 \%)) ; 80-90 \%$ of the precipitation norm occurred in $4.8 \%$ of cases (December $2015(81.6 \%)$, July $2009(81.9 \%)$ and $2010(89.0 \%)$, September $2003(82.0 \%)$ and $2006(83.7 \%)$, March 2016 (83.9\%), 2012 (87.4\%) and 2004 (89.0\%), May 2009 (84.0\%), February 2006 $(84.6 \%)$, October $2011(86.5 \%)) ; 90-100 \%$ of the precipitation norm occurred in 3.9\% of cases (July 2004 (91.3\%) and 2000 (94.3\%), April 2002 (92.7\%) 
and 2006 (97.0\%), March 2003 (92.9\%), February 2003 (95.7\%), May 2004 (97.8\%), November 2004 (98.9\%), January 2018 (100.0\%)) (Fig. 4).

Maximum precipitation - 393.9 and $374.2 \%$ of the norm - occurred in March and September 2013.

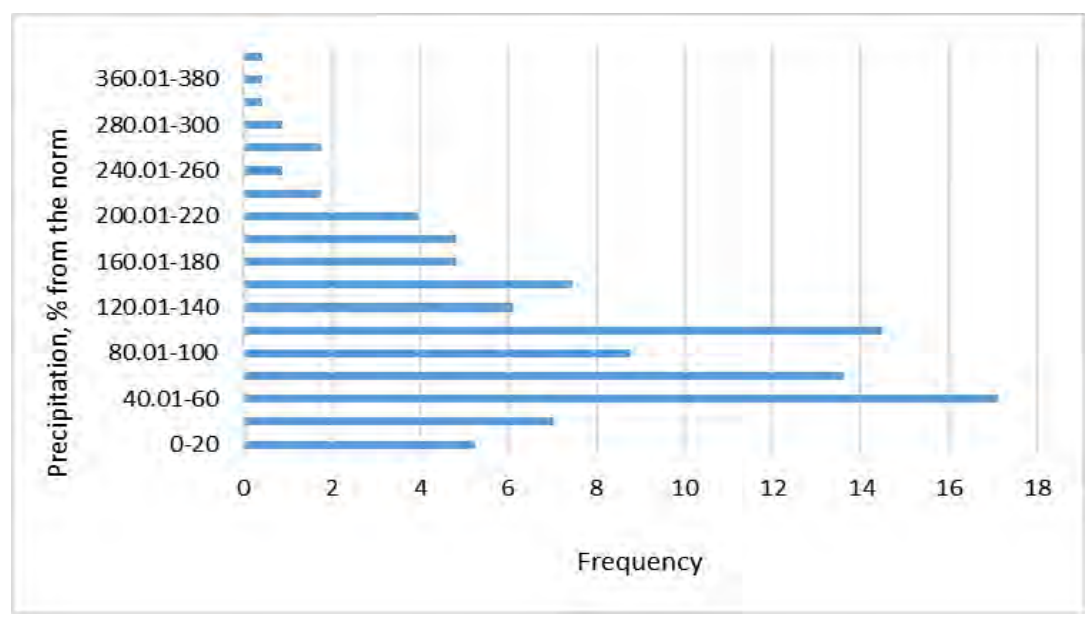

Fig. 4. Distribution of precipitation amount which occurred in Zhytomyr during the period of observations

There were certain changes in the precipitation amount in the context of months in Zhytomyr over 2000-2018 (Fig. 5).

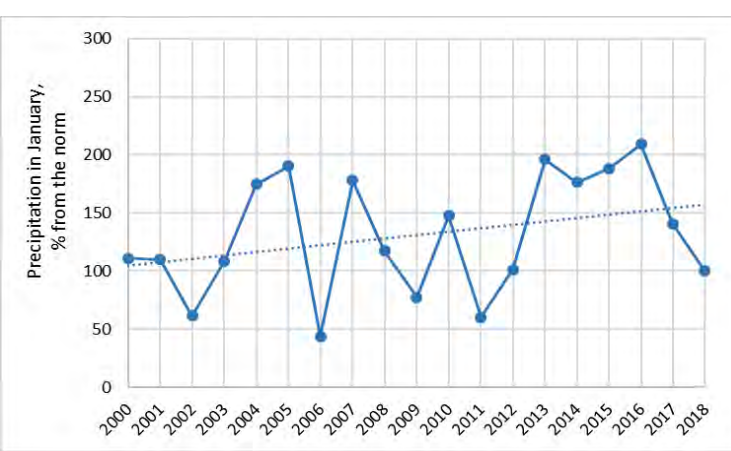

a)

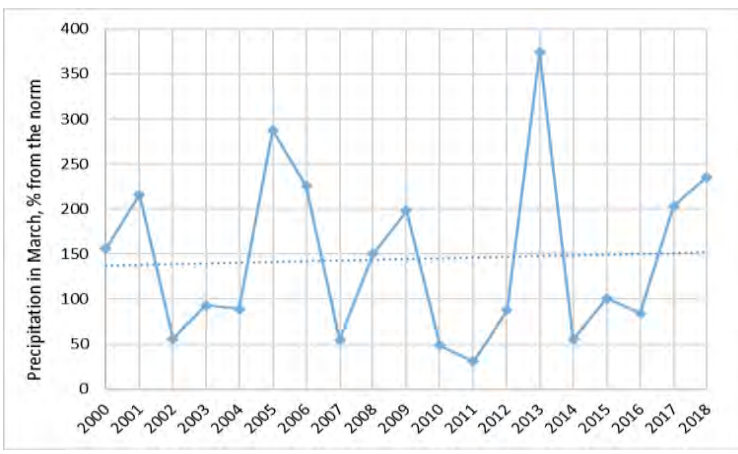

c)

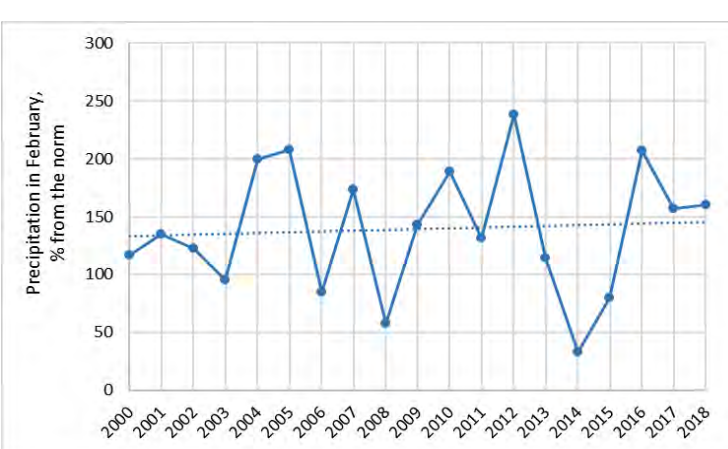

b)

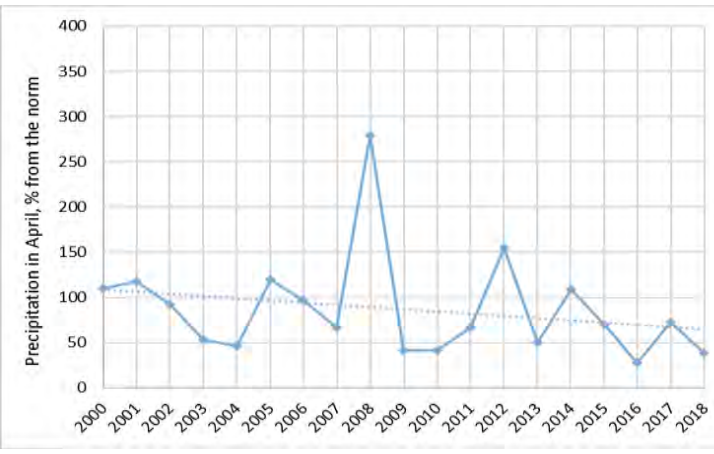

d)

Fig. 5. Changes in the precipitation amount in the context of months in Zhytomyr during 2000 - 2018 


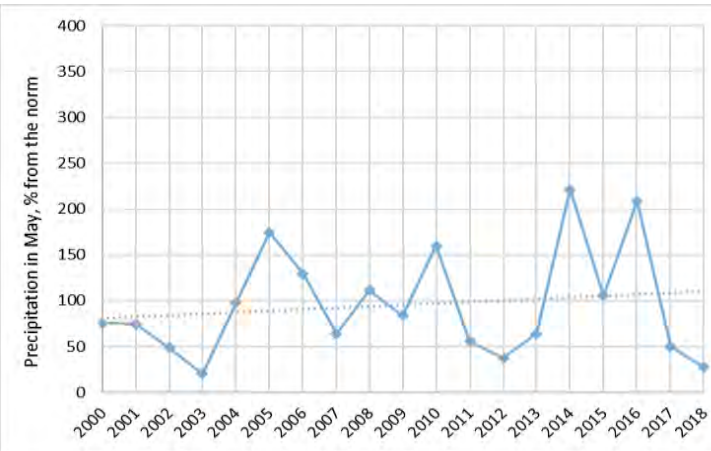

e)

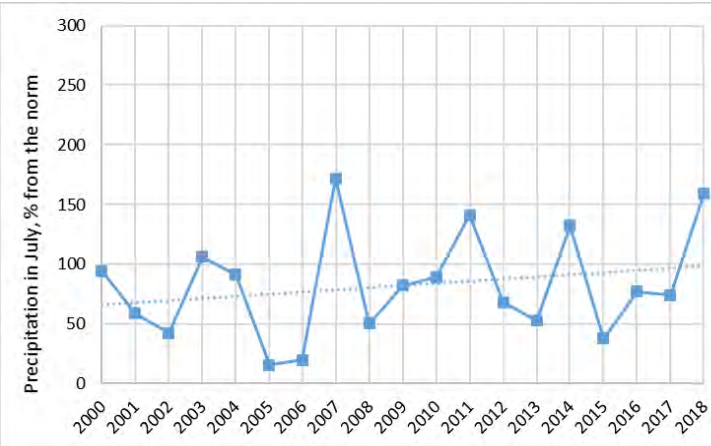

g)

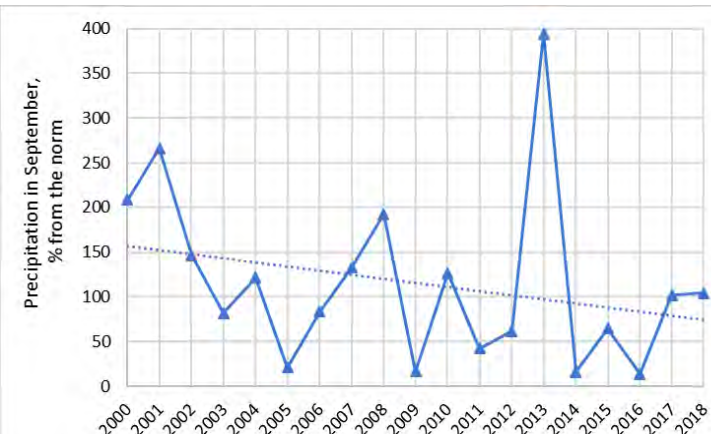

i)

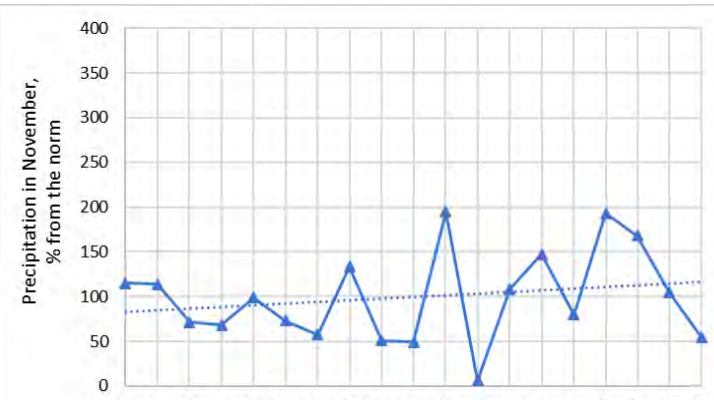

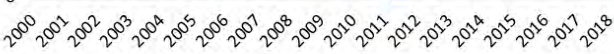

k)

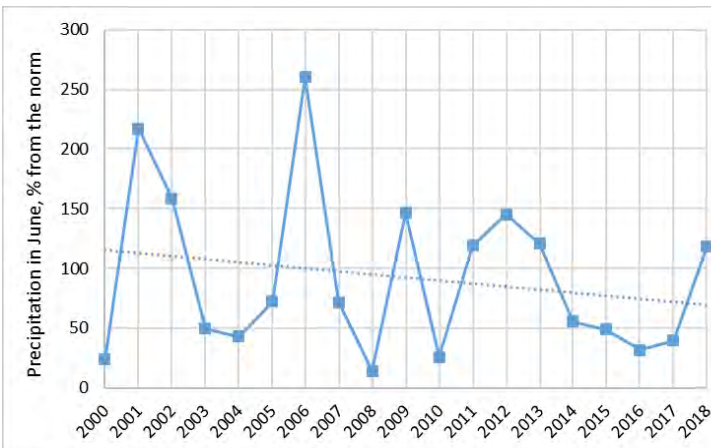

f)

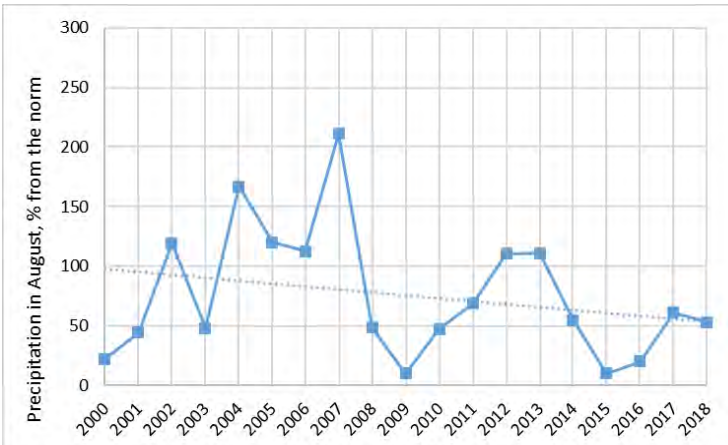

h)

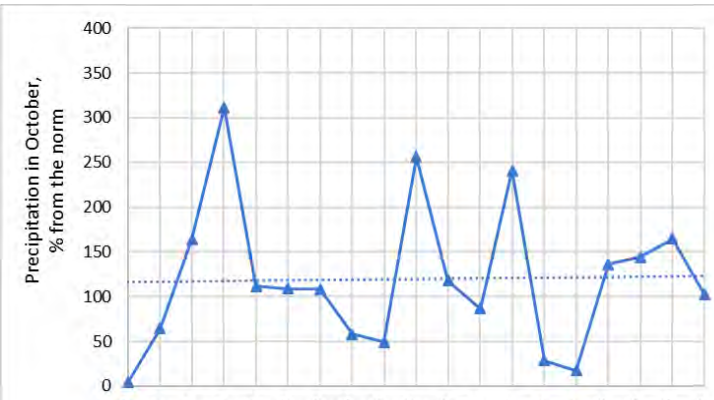

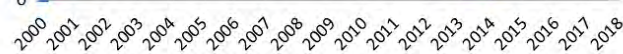

j)

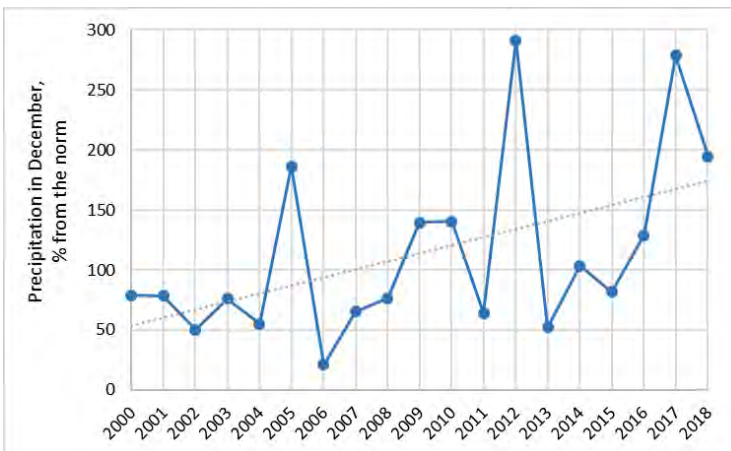

l)

Fig. 5. (Continued) 
Over a 19-year period under investigation, there is a trend towards precipitation enhancement in winter months (Fig.5 $a, b, l$ ), in March (Fig. 5c), May (Fig. 5d), July (Fig. 5e), October (Fig. 5j) and November (Fig. 5k). It should be noted, though, that despite this trend, average amount of precipitation in May over 2000-2018 was $95.3 \%$ (Fig. 5e), in July $82.2 \%$ (Fig. $5 g$ ), in November $99.4 \%$ of the norm (Fig. $5 k$ ).

April (Fig. 5d) and the period from June to August (Fig. $5 f, g, h$ ) were characterized by a clear trend towards precipitation reduction. On average, during this period precipitation amount was $87.1,92.7,82.2$ and $75.8 \%$ of the precipitation norm.

Despite the trend towards precipitation reduction, on average precipitation amount in February was $139.4 \%$ of the norm (Fig. $5 b$ ), in March $144.5 \%$ of the norm (Fig. 3.5c), in September $115.6 \%$ of the norm (Fig. $5 i$ ).

It should be pointed out that the highest coefficients of variation were peculiar to precipitation in autumn and summer seasons $-67.8 \%$ and $66.8 \%$, respectively. In the context of months, they were peculiar to September $83.7 \%$.

\section{Assessment of deviation essentiality for air temperature and precipitation amount from average annual values}

The deviation essentiality from average annual values was assessed for air temperature and precipitation amount based on calculation and analysis of relevant coefficients $-\mathrm{CDE}_{\mathrm{T}}$ (Coefficient of deviation essentiality for air temperature) and $\mathrm{CDE}_{\mathrm{P}}$ (for precipitation amount).

A third of the years under investigation was characterized by the temperature conditions that differed significantly from the average annual values and were approximate to extreme ones (Fig. 6,7).

In terms of $\mathrm{CDE}_{\mathrm{T}}$ values, there were significant deviations from the average annual values in 2002. $\left(\left|\mathrm{CDE}_{\mathrm{T}}\right|=1.29\right), 2007\left(\left|\mathrm{CDE}_{\mathrm{T}}\right|=1.22\right), 2008$ $\left(\left|\mathrm{CDE}_{\mathrm{T}}\right|=1.26\right)$, and also since 2015 (2015 was characterized by the maximum value $\left|\mathrm{CDE}_{\mathrm{T}}\right|-1.53$ ) (Fig. 6a).

Over a 19-year period under investigation, months form the following order series (Fig. 6b): conditions similar to usual ones: April (73.7\%) > May, July, October and November (68.4\%) $>$ January, March, August, September and December $(63.2 \%)>$ February $(57.9 \%)>$ June $(52.6 \%)$; conditions that significantly differ from the average: June $(47.4 \%)>$ February $(42.1 \%)>$ March and August (36.8\%) > January, May, July, September and December $(31.6 \%)>$ October and November $(26.3 \%)>$ April $(21.1 \%)$.

In $2.6 \%$ of cases (Fig. $6 b, 7$ ), the conditions were approximate to uncommon (extreme). These were the months when the record air temperature was observed: January 2007 (average monthly temperature was $2.0^{\circ} \mathrm{C}$, while the norm is $6^{\circ} \mathrm{C}$ ), April 2018 (average monthly temperature was 
13.6 ${ }^{\circ} \mathrm{C}$, which exceeded the norm by $5.9^{\circ} \mathrm{C}$ ), September 2015 (average monthly temperature exceeded the norm by $4^{\circ} \mathrm{C}$ ), October 2008 (average monthly temperature exceeded the norm by $3.6^{\circ} \mathrm{C}$ ), November 2010 (average monthly temperature exceeded the norm by 4.2 times) and December 2003 (average monthly temperature was $7.0^{\circ} \mathrm{C}$, while the norm is $2.7^{\circ} \mathrm{C}$ ).

$31.6 \%$ of years under investigation were characterized by conditions that significantly differed from the average annual values (the value of $\left|\mathrm{CDE}_{\mathrm{P}}\right|$ was within 1-2): $2001\left(\left|\mathrm{CDE}_{\mathrm{P}}\right|=1.3\right), 2003\left(\left|\mathrm{CDE}_{\mathrm{R}}\right|=1.1\right), 2007,2011$ and 2015 $\left(\left|\mathrm{CDE}_{\mathrm{R}}\right|=1.4\right)$, and also $2012\left(\left|\mathrm{CDE}_{\mathrm{P}}\right|=1.5\right)$. Conditions close to extreme $\left(\left|\mathrm{CDE}_{\mathrm{P}}\right|>2\right)$ were observed in $2013\left(\left|\mathrm{CDE}_{\mathrm{P}}\right|=2.01\right)$ (Fig. 6 c $_{\mathrm{c}}$.

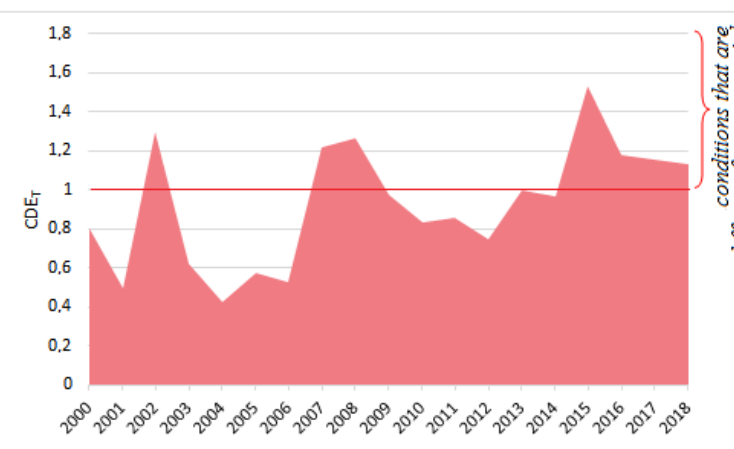

a)

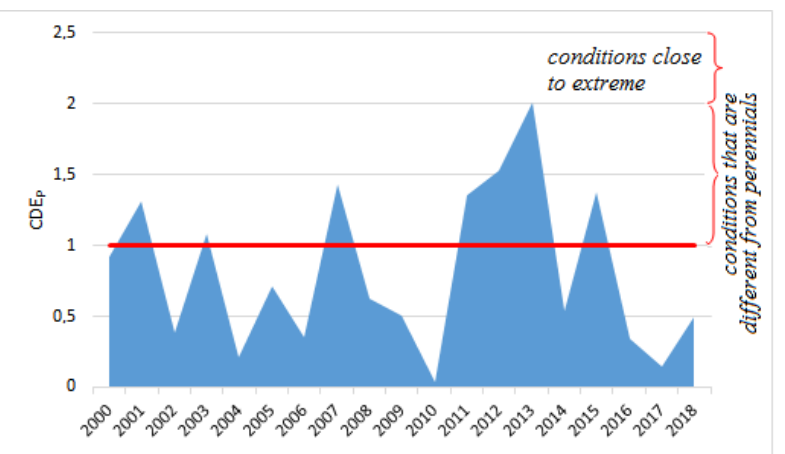

c)

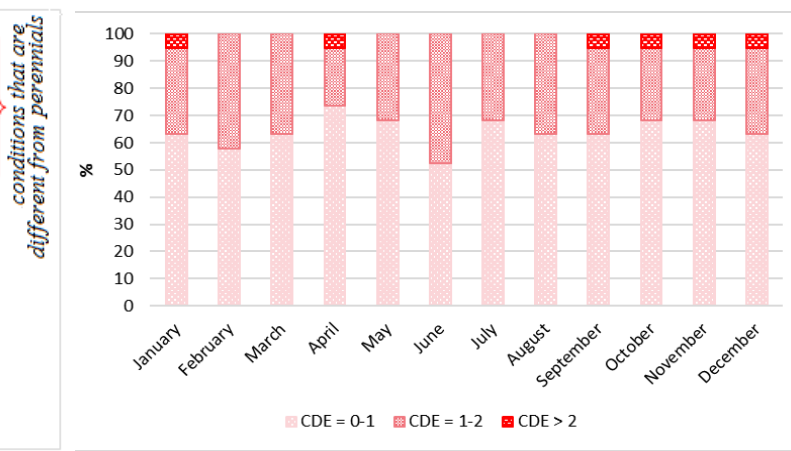

b)

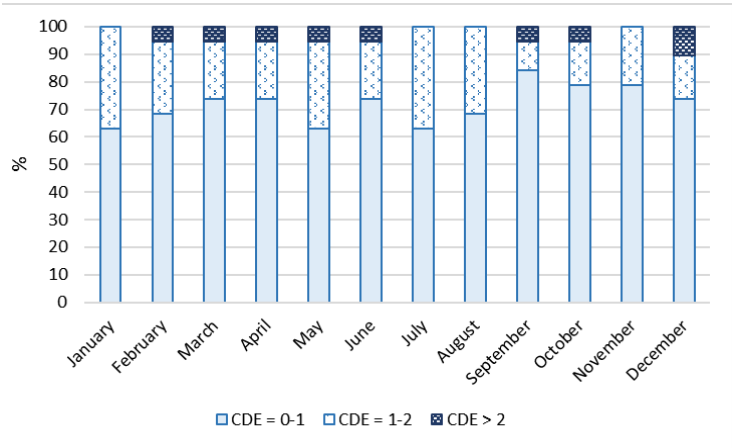

d)

Fig. 6. Coefficients of deviation essentiality for air temperature $\left(\mathrm{CDE}_{\mathrm{T}}\right)$ and precipitation amount $\left(\mathrm{CDE}_{\mathrm{P}}\right)$ from annual values during 2000-2018 and in the context of months

The coefficient of deviation essentiality for the amount of precipitation in terms of months during 2000-2018 also varied (Fig. 6d). September is characterized by the greatest share of conditions that are close to usual ones (84.2\%). $78.9 \%$ of conditions close to usual ones were observed in October and November, $73.7 \%$ in March, April, June and December, $68.4 \%$ in February and August, $63.2 \%$ in January, May and July. 


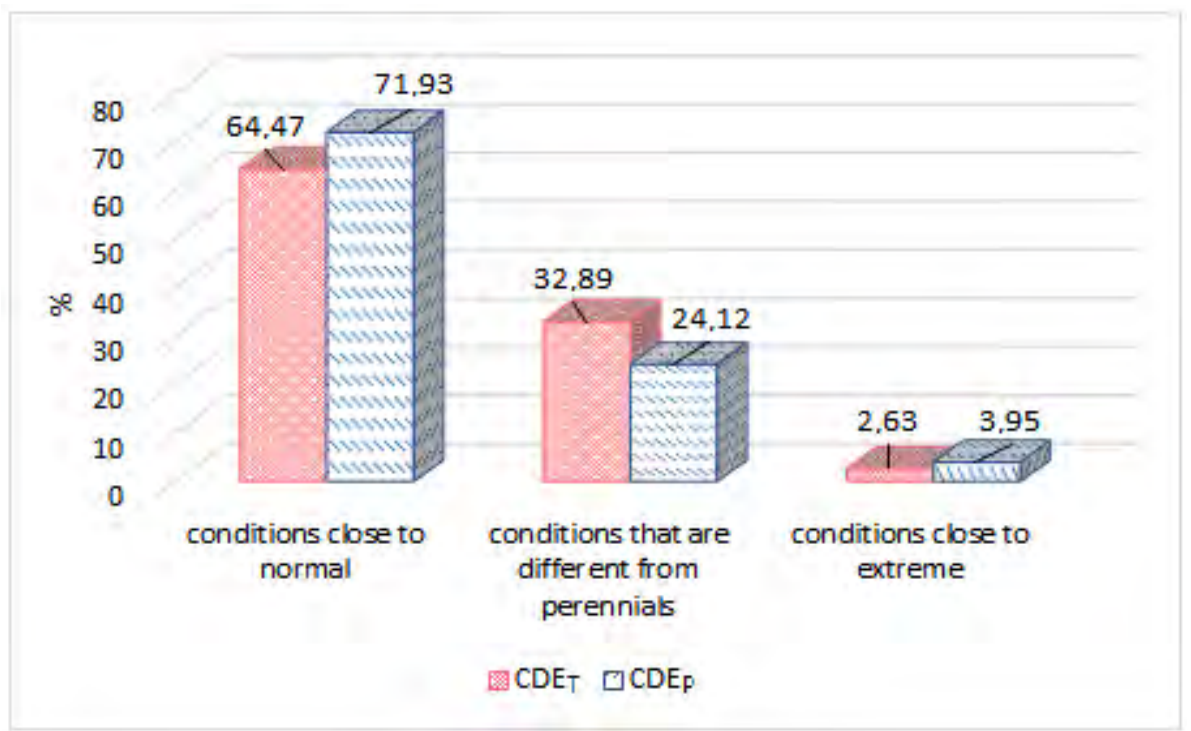

Fig. 7. Share of months according to the coefficients of deviation essentiality for air temperature $\left(\mathrm{CDE}_{\mathrm{T}}\right)$ and precipitation amount $\left(\mathrm{CDE}_{\mathrm{R}}\right)$ for $2000-2018$

As for conditions that differed from the annual data significantly (value of $\left|\mathrm{CDE}_{\mathrm{R}}\right|$ within the range 1-2), their share in January and July was $36.8 \%$, in May and August 31.6\%, in February 26.3\%, in May, April, June and November $21.1 \%$, in October and December 15.8\%, in September 10.5\% (Fig. 6d).

Conditions approximate to uncommon (extreme) ones occurred only in $3.9 \%$ of cases (Fig. $6 d, 7$ ). In December extreme conditions occurred only in 2012 and 2017 (average precipitation amount exceeded the norm by almost 3 times), in February 2012 (the amount of precipitation during a month was $66.7 \mathrm{~mm}$, while the norm is $28.0 \mathrm{~mm}$ ), in March 2013 (the amount of precipitation exceeded the norm by 3.7 times), in April 2008 (the amount of precipitation was $280 \%$ of the monthly norm), in May 2014 (221.5\% of the norm was observed), in June 2006 (the amount of precipitation during a month was $197.8 \mathrm{~mm}$, while the norm is $76.0 \mathrm{~mm}$ ), in September 2013 (the amount of precipitation was $393.9 \%$ of the monthly norm) and October 2003 (the amount of precipitation was $311.5 \%$ of the norm).

Given the fact that the consequences of climate change are most noticeable at the local level, measures aimed at adaptation to climate change should also be taken at the local level. Thus, the issues of climate change should be considered as essential local issues, which will be an important step in overcoming the lack of awareness at the local level, especially for those groups of population that are at risk.

\section{CONCLUSIONS}

Zhytomyr is characterized by a trend towards change of air temperature and precipitation amount. During 2000-2018 air temperature increased by $1.9^{\circ} \mathrm{C}$ 
compared to the climatic norm (over 2000-2010 air temperature increased by $1.7^{\circ} \mathrm{C}$, while over $2011-2018$ by $2.2^{\circ} \mathrm{C}$ ). 2015 was the warmest year over the period of investigation, while the highest temperature rise occurred in the first part of the year. In the context of 2000-2018, the deviation from the norm ranged from $0.9(2004)$ to $3.2(2015)^{\circ} \mathrm{C}$. Average monthly temperature for all months during 2000-2018 exceeded the norm by 0.8 (October) -2.6 (July) ${ }^{\circ} \mathrm{C}$. The values of average monthly temperature during winter season over 2000 2018 increased by $2.3^{\circ} \mathrm{C}$, during spring and summer seasons by $2.1^{\circ} \mathrm{C}$, and during autumn season by $1.2^{\circ} \mathrm{C}$. Only $1.3 \%$ of values of average monthly temperature met the climatic norm (May 2008, June 2000 and November 2001).

Over the period under investigation 2000-2018, average amount of precipitation was $612.3 \mathrm{~mm}$ (climatic norm is $607 \mathrm{~mm}$ ). Over a 19-year period under investigation, there was a trend towards precipitation enhancement in relation to the norm for winter months, March and October. A clear trend towards precipitation reduction was observed for April and period from June to August, when the amount of precipitation was 87.1, 92.7, 82.2 and $75.8 \%$ of the norm. Over the past 19 years, the minimum amount of precipitation $-1.4 \mathrm{~mm}$ - was observed in October 2000, while the maximum amount - $200.9 \mathrm{~mm}$ - in September 2013.

Using the coefficient of deviation essentiality it has been found that temperature climatic condition were close to usual ones in $64.5 \%$ of cases, $32.9 \%$ differed significantly, $2.6 \%$ were approximate to uncommon (extreme). In terms of coefficient of deviation essentiality for the precipitation amount, it has been established that climatic conditions were close to usual ones in $71.9 \%$ of cases, $24.1 \%$ differed significantly, and $3.9 \%$ were approximate to uncommon (extreme) conditions.

Given the fact that the consequences of climate change are most noticeable at the local level, measures aimed at adaptation to climate change should also be taken at the local level.

\section{SUMMARY}

The article covers the trends in the manifestations of climate change in Zhytomyr during 2000-2018 based on the calculation of coefficients of deviation essentiality. It has been found that during $2000-2018$ the city was characterized by a trend towards temperature rise (by $1.9^{\circ} \mathrm{C}$ compared to the climatic norm). 2015 was the warmest year over the period of investigation. Average monthly temperature for all months exceeded the norm by 0.8 (October) -2.6 (July) ${ }^{\circ} \mathrm{C} .1 .3 \%$ of values of average monthly temperature met the climatic norm. Average precipitation amount during the period under investigation was $612.3 \mathrm{~mm}$ (the norm is $607 \mathrm{~mm}$ ). Over a 19-year period under investigation, there was a trend towards precipitation enhancement in relation to the norm for winter months, March and October, while a trend towards 
precipitation reduction was observed for April and period from June to August. The minimum amount of precipitation $-1.4 \mathrm{~mm}$ - was observed in October 2000, whereas the maximum amount - $200.9 \mathrm{~mm}$ - in September 2013. Temperature climatic conditions and precipitation amount were close to usual ones in $64.5 \%$ and $71.9 \%$ of cases, $32.9 \%$ and $24.1 \%$ differed significantly, while $2.6 \%$ and $3.9 \%$ were approximate to uncommon (extreme) conditions.

\section{REFERENCES}

1. Про Цілі сталого розвитку України на період до 2030 року : Указ Президента України від 30 верес. 2019 р. № 722/2019. URL: https://zakon.rada.gov.ua/rada/show/722/2019

2. Про Основні засади (стратегію) державної екологічної політики України на період до 2030 року : Закон України від 28 лют. 2019 р. № 2697-VIII. URL: https://zakon.rada.gov.ua/laws/show/2697-19

3. Концепція реалізації державної політики у сфері зміни клімату на період до 2030 року : Розпорядження Кабінету Міністрів України від 07 груд. 2016 p. № 932-p. URL: https://zakon.rada.gov.ua/laws/show/9322016

4. Annual Report 2017 : UN Climate Change. URL: https://unfccc.int/ resource/annualreport

5. Climate Change 1995 : Second Assessment : Report of the intergovernmental panel on climate change. URL: https://www.ipcc.ch/site/ assets/uploads/2018/06/2nd-assessment-en.pdf

6. Climate Change 2001: The Scientific Basis. Contribution of Working Group I to the Third Assessment Report of the Intergovernmental Panel on Climate Change / J.T. Houghton at al. Cambridge University Press, Cambridge, United Kingdom and New York, NY, USA, 2001. 881 p. URL: https://www.ipcc.ch/site/assets/uploads/2018/03/WGI_TAR_full_report.pdf

7. Climate Change 2007: Synthesis Report. Contribution of Working Groups I, II and III to the Fourth Assessment Report of the Intergovernmental Panel on Climate Change / Core Writing Team, R.K Pachauri, A. Reisinger. (eds.). IPCC, Geneva, Switzerland, 2007. 104 p. URL: https://www.ipcc.ch/ site/assets/uploads/2018/02/ar4_syr_full_report.pdf

8. Climate Change 2014: Synthesis Report. Contribution of Working Groups I, II and III to the Fifth Assessment Report of the Intergovernmental Panel on Climate Change / Core Writing Team, R.K. Pachauri, L.A. Meyer (eds.). IPCC, Geneva, Switzerland, 2014. 151 p. URL: https://www.ipcc.ch/ site/assets/uploads/2018/05/SYR_AR5_FINAL_full_wcover.pdf

9. Climate Change and Land 2019: An IPC̄C Special Report on climate change, desertification, land degradation, sustainable land management, food security, and greenhouse gas fluxes in terrestrial ecosystems. URL: https://www.ipcc.ch/site/assets/uploads/2019/08/Edited-SPM_Approved_

Microsite_FINAL.pdf 
10. Climate Change: The IPCC Scientific Assessment - 1st Report : World meteorological organization. URL: https://www.ipcc.ch/site/assets/uploads/ 2018/03/ipcc_far_wg_I_full_report.pdf

11. The Intergovernmental Panel on Climate Change, IPCC. URL: https://www.ipcc.ch

12. World Meteorological Organization. URL: https://public.wmo.int/en

13. Global Warming of $1.5{ }^{\circ} \mathrm{C}$ : IPCC Special Report on the impacts of global warming of $1.5{ }^{0} \mathrm{C}$ above pre-industrial levels and related global greenhouse gas emission pathways, in the context of strengthening the global response to the threat of climate change, sustainable development, and efforts to eradicate poverty. IPCC, Switzerland, 2018. 32 p. URL: https://report.ipcc.ch/sr15/pdf/sr15_spm_final.pdf

14. Кліматична дипломатія в СС: висновки та рекомендації для України: аналітичний документ. Львів : Експертно-дорадчий центр «Правова аналітика», 2017. 39 c. URL: https://www.rac.org.ua/uploads/ content/371/files/climate-diplomacy.pdf

15. Features of climate change on Ukraine: scenarios, consequences for nature and agroecosystems / S. Boychenko at al. Proceedings of National Aviation University. 2016. Vol. 69. № 4. P. 96-113. DOI: https://doi.org/ 10.18372/2306-1472.69.11061

16. Польовий А.М., Божко Л.Ю. Характеристика радіаційно-теплових ресурсів в Україні на період до 2050 р. в умовах зміни клімату. Украйнський гідрометеорологічний журнал. 2016. № 17. C. 70-78. URL: http://nbuv.gov.ua/UJRN/Uggj_2016_17_10

17. Зміна погодних умов на території України в умовах зміни клімату / В.М. Хохлов та ін. Украӥнський гідрометеорологічний журнал. 2016. № 17. C. 31-37. URL: http://nbuv.gov.ua/UJRN/Uggj_2016_17_6

18. Осадчий B.I., Бабіченко В.М. Температура повітря на території України в сучасних умовах клімату. Український географічний журнал. 2013. № 4. C. 32-39. DOI: https://doi.org/10.15407/ugz2013.04.032

19. Прокопенко К.О., Удова Л.О. Сільське господарство України: виклики і шляхи розвитку в умовах зміни клімату. Економіка $i$ прогнозування. 2017. № 1. C. 92-107. DOI: https://doi.org/10.15407/ eip2017.01.092

20. Хромяк В.М., Наливайко В.В. Ризики ведення рослинництва в умовах Північно-східного Степу в зв'язку зі зміною клімату. Вісник аграрної науки. 2016. Вересень. С. 17-24. DOI: https://doi.org/10.31073/ agrovisnyk201609-03

21. Гребенюк Н.П. Характеристика повторюваності сильних злив на території України в умовах сучасних змін клімату. Гідрологія, гідрохімія $i$ гідроекологія. 2014. T. 1. C. 96-101. URL: http://nbuv.gov.ua/UJRN/ glghge_2014_1_13

22. Балабух В.О. Регіональні прояви глобальної зміни клімату в Тернопільській області та можливі їх зміни до середини XXI ст. Наукові 
записки Тернопільського національного педагогічного університету імені Володимира Гнатюка. Сер. Географія. 2014. № 1. С. 43-54. URL: http://nbuv.gov.ua/UJRN/NZTNPUg_2014_1_9

23. Валерко Р.А. Екологічна оцінка змін клімату на території м. Коростень Житомирської області. Вісник ЖНАЕУ. 2015. № 2 (50). T. 1. C. $46-54$.

24. Герасимчук Л.О., Валерко Р.А., Мартенюк Г.М. Тенденції зміни клімату на території м. Новоград-Волинський Житомирської області. Наукові горизонти. 2018. № 2 (65). С. 42-50.

25. Ретроспективний аналіз погодних умов у зоні діяльності Миронівського інституту пшениці / В.В. Кириленко та ін. Миронівський вісник. 2016. Вип. 2. С. 87-97. DOI: https://doi.org/10.21498/25187910.0.2016.119548

26. Регіональні зміни клімату як причина гострих всихань сосняків Волинського Полісся / А.І. Гетьманчук та ін. Науковий вісник НЛТУ України. 2017. Vol. 27. № 1. P. 120-124. DOI: https://doi.org/10.15421/ 40270127

27. Староватов А.А. Некоторые аспекты изменения климата земли. Web of Scholar. 2018. № 6 (24). T. 2. C. 52-54. DOI: 10.31435/rsglobal_wos/ $12062018 / 5754$

28. Ho E.H., Budescu D.V. Climate uncertainty communication. Nat. Clim. Chang. 2019. № 9. P. 802-803. DOI: 10.1038/s41558-019-0606-6

29. Highlights of Climate Change Impacts in the United States: The Third National Climate Assessment, USGCRP / Jerry M. Melillo et al. (eds.). Washington, DC: U.S. Government Printing Office, 2014. URL: http://www.globalchange.gov/sites/globalchange/files/NCA3_Highlights_Lo wRes-small-FINAL_posting.pdf

30. Massimiliano Pasqui, Edmondo Di Giuseppe. Climate change, future warming, and adaptation in Europe. Animal Frontiers. 2019. Vol. 9. № 1. P. 6-11. URL: https://doi.org/10.1093/af/vfy036

31. Педь Д.А. О показателе засухи и избыточного увлажнения. Tpydbl Гидрометиентра СССР. 1975. Вып. 156. С. 19-38.

\section{Information about authors:} Herasymchuk L. O.,

Candidate of Agricultural Sciences, Associate Professor at the Department of General Ecology Zhytomyr National Agroecological University 7, Staryi blvd., Zhytomyr, 10008, Ukraine Valerko R. A.,

Candidate of Agricultural Sciences, Associate Professor at the Department of General Ecology Zhytomyr National Agroecological University 7, Staryi blvd., Zhytomyr, 10008, Ukraine 